DOI:http://dx.doi.org/10.18524/1810-4215.2019.32.182527

\title{
JOVIAN DECAMETER RADIO EMISSION: TO THE QUESTION ON THE SIZE OF SOURCES
}

\author{
N.O. Tsvyk \\ Institute of Radio Astronomy of NASU, \\ Kharkiv, Ukraine, natalitsv69@gmail.com
}

\begin{abstract}
There are debated the questions on size and properties of sources of Jupiter DAM radio emission (JRE). The evolution and the parameters of the sources in the DAM Io-B-storm of October 30, 2008 , consisting of a large number of S-bursts, and interspersed with L-bursts and N-bursts, are analyzed in detail. It is shown that S-bursts in this storm are most likely to occur in the northern hemisphere of Jupiter at heights $(0-0.2) R_{j}$ and at longitudes $\lambda_{I I I s}=(195-220)^{\circ}$ (when Jupiter is deployed to the
\end{abstract} observer CML $\left.=\lambda_{I I I}=130-160^{\circ}\right)$. The onset of the Io-B-storm is associated with sources at high altitudes, and over time the sources drop down to Jupiter (as the observed S-burst frequencies increase with time). The possibility of the appearance of L- and N-bursts on the background of S-bursts is discussed. L-bursts can arise from the southern hemisphere of Jupiter, at a height of $0.2 R_{j}$. And N-bursts can most likely be located in the northern hemisphere at $\lambda_{I I I s}=66^{\circ}$ at a height of $0.2 R_{j}$. Using the spectral data on the JRE from 30.10.08, the sizes (thickness and length) of filament-like sources of JRE - electron beams were determined, and the parameters of the MHD (Alfven) waves that activating the JRE bursts. It is shown that the L-radiation sources most likely appear to be thin filaments elongated to magnetic field lines, with a thickness of more then $10 \mathrm{~km}$, and up to $2000 \mathrm{~km}$ in length. And the sources of S-radiation look like links with filament-like emissions less than 1 $\mathrm{km}$ thick (10-100 strands in a bundle) and up to 300 $\mathrm{km}$ in length flying at a speed of (0.05-0.1) c away from Jupiter. The observed A-wave velocities are 2-3 times slower than the A-wave velocity predicted theoretically (about $0.001 \mathrm{c}$, in light velocity units). Frequency $(0.2-1 \mathrm{MHz})$ and temporal (up to $1 \mathrm{~min}$ ) diffraction modulation of "lanes" confirms the size of the S-sources less than $200 \mathrm{~km}$. Conclusions are made about the theoretical prerequisites for the appearance of S-bursts with observed parameters. Estimates of the radiation intensity of S-sources indicate an additional increase in the radiation of the source near the generation region; this indicates a non-homogeneous structure of the environment in the active regions of the Jupiter magnetosphere. The thin transverse structure of the S-sources can be explained by the mechanism of plasmas fluctuations with periods of $\tau=\tau_{e a}=10 \mathrm{~ms}$, and with the peculiarities of the bunches of plasma clots that lead to electron leakage and to the emission of plasma plaits. The observed deceleration of the MHD wave velocities can be explained by the influence of the Io - Jupiter flow tube.

Keywords: Jupiter, DAM radio emission, MHD waves, source sizes.

АНОТАЦЯ. Розглянуто питання про розміри i властивості джерел декаметрового радіовипромінювання Юпітера (ДРЮ). Детально проаналізовано еволюцію і визначено параметри джерел в Іо-В-бурі від 30 жовтня 2008 р., що складається 3 великого числа S-сплесків, i перемежається 3 L-сплесками і N-сплесками. Показано, що S-сплески в цій бурі, швидше за все, виникають в північній півкулі Юпітера на висотах $(0-0.2) R_{j}$ i на довготах $\lambda_{I I I s}=(195-$ $220)^{\circ}$ (коли Юпітер повернутий до спостерігача $\left.\mathrm{CML}=\lambda_{I I I}=130-160^{\circ}\right)$. Початок Iо-В-бурі пов'язаний 3 джерелами на великих висотах, i 3 часом джерела опускаються вниз до Юпітера (притому, що спостережувані частоти S-сплесків з часом підвищуються). Обговорюється можливість появи L- i N-сплесків на фоні S-сплесків. Так, L-сплески можуть бути пов'язані 3 джерелами 3 південноі півкулі Юпітера, на висоті $(0-0.2) R_{j}$. При цьому, N-сплески, швидше за все, можуть виникать в північній півкулі на $\lambda_{I I I s}=66^{\circ}$ і на висоті $0.2 R_{j}$. Використовуючи спектральні дані по ДРЮ від 30.10.08, визначено розміри (товщина і довжина) нитко-подібних джерел ДРЮ-пучків електронів, і параметри МГД (альвенівських) хвиль, тих, що активують сплески ДРЮ. Показано, що джерела L-випромінювання, швидше за все, виглядають як тонкі нитки, витягнуті уздовж магнітного поля, товщиною більше ніж 10 км, і довжиною до 2000 км. А джерела S-випромінювання виглядають як зв'язки з нитко-подібних викидів товщиною менше 
1 км (по 10-100 ниток в зв'язці) і довжиною до 300 км, що летять зі швидкістю (0.05-0.1)с в сторону від Юпітера. Спостережувані швидкості А-хвиль в 2-3 рази повільніші від значення швидкості А-хвилі, передбаченоі теоретично (близько 0.001 c, в одиницях швидкостей світла). Частотна $(0.2-1$ МГц) і часова (до 1 хв.) дифракційна модуляція ДРЮ "доріжками" підтверджує розміри S-джерела менше 200 км. Зроблено висновки про теоретичні передумови появи Sсплесків ДРЮ зі спостережуваними параметрами. Оцінки інтенсивності випромінювання S-джерел вказує на додаткове посилення випромінювання джерела поблизу області генераціi; це говорить про неоднорідну структуру середовища в активних областях магнітосфери Юпітера. Тонка поперечна структура S-джерел може бути пояснена механізмом флуктуацій плазми 3 періодами $\tau=\tau_{e a}=10 \mathrm{мc}$, і 3 особливостями бунчіровки плазмових згустків, що приводять до витікання електронів і до викидів плазмових джгутів. Спостережуване уповільнення швидкостей МГДхвиль можна пояснити впливом потоковоі трубки Іо - Юпітер.

Ключові слова: Юпітер, декаметрове радіовипромінювання, МГД хвилі, розміри джерел.

\section{Introduction}

Jupiter as one of the most powerful source of radio emission in the solar system was discovered in 1955 (Burke and Franklin; see more: Ryabov and Gerasimova, 1990). The Jupiter's radio emission (JRE) has a maximum at DAM frequency range, and it consists of the bright (up to $10^{7} \mathrm{Jy}$ ) short S-bursts of millisecond duration and the slight less brightly (up to $10^{6} \mathrm{Jy}$ ) long L-bursts of second duration. At the frequency range of higher then $100 \mathrm{MHz}$, the continuous synchrotron radiation is observed in the equatorial region of Jupiter at heights of $2 R_{j}$. At the same height $\left(2 R_{j}\right)$, in the $\mathrm{kHz}$ frequency range there is observed the relatively bright (up to $10^{5} \mathrm{Jy}$ ) quasi-periodic 10-minute bursts, the nature and shape of which are similar to III-type solar bursts. And the same 10-minute frequency modulation is exhibit in all sources of DAM radiation that connected with the Alfven wave modulation features.

We are interested here the main and fine sizestructure of DAM Jupiter's radio emission sources on the example of one of observed storms (the storm at $30.10 .2008)$. It give us to find out on the mechanisms of DAM JRE generation, the form of the radiation source, and the specific features of the development of the storm.

\section{Properties and mechanisms of the DAM Jovian radio emission}

There was established that the radiation pattern (RP) of JRE has the form of a hollow cone with a solution of $(60-90)^{\circ}$. In this regard, the observed sources are usually located near the limb of Jupiter, and the longitude of the source is shifted relative to the central meridian of Jupiter by approximately the magnitude of the RP (which introduces us ambiguity). In addition, Jupiter's DAM sources correlate with the phaseposition of the Io satellite $\left(\Phi_{I} O\right)$, and prefer to appear at certain active longitudes (A, B, C, D sources). Therefore, for Io-correlated storms, the position of the source in longitude is uniquely determined as:

$$
\lambda_{I I I s}=\lambda_{I I I}-\Phi_{I o}+180^{\circ}-\Delta \lambda,
$$

where $\Delta \lambda \simeq 20^{\circ}$ is the source shift-advancing angle (Ryabov \& Gerasimova, 1990).

The sources of L-type exhibit predominantly longitudinal correlation; and S-sources predominantly correlate with the Io phase. The latitude of the sources of DAM radiation can be determined only on the assumption that the sources in the Io-dependent storms are attached to the Io-Jupiter flux tube and are located near the northern or southern foot of the tube. In this case, it is usually considered that DAM radiation is generated in the form of fast extraordinary $\mathrm{X}$-waves, and then in the Leblanc model (Leblanc, et al., 1993) the right-polarized radio wave sources $(\mathrm{A}, \mathrm{B})$ are tied to the northern Jupiter's hemisphere, and left-polarized sources (C, D) are tied to the southern hemisphere.

The mechanism of Jupiter's DAM radiation can be associated with one of the instabilities of electromagnetic or plasma waves near the cyclotron frequency, that developing (running) under the condition of resonance between waves and particles in a low-density non-equilibrium plasma $\left(\omega_{p e}<<\omega_{b e}\right)$ :

$$
\omega-s \omega_{b e}-k_{\|} v_{\|}=0,
$$

where $s=0,-1, \ldots$ There is most often it is believed that instability arises at the $s=-1$ resonance for fast extraordinary X-modes, that give us the Maser cyclotron radiation (MCR) which observed as L-bursts of JRE (Wu, 1985, Melrose, 1986, others). And the generation of S-bursts can occur due to both MCR instability ( $s$ $=-1$ ) and the Cherenkov plasma instability (CR) at resonance of $s=0$ from bunched fast electron beams (see Zaitsev, et al., 1986; Boev, et al.,1991).

Moreover, there is necessary the generation of MCR into an efficient pumping of electrons with a cone velocity distribution $\left(T_{\perp}>T_{\|}\right)$and beam elongated. Then the energy of nonequilibrium weakly relativistic $(\gamma-1>0.001)$ electrons is pumped maserly into fast extraordinary wave and into plasma waves with a radiation pattern $\mathrm{RP}=(60-90)^{\circ}$ to the magnetic field line in the source. 
The Cherenkov radiation $(\mathrm{CR})$ mechanism may be even more efficiently than the maser mechanism, and it converts the energy of electron accelerated in electron beams into plasma Z-waves near the upper hybrid frequency. However, these $\mathrm{Z}$-waves not go away the source; and there is required an additional conversion of Z-waves into fast electromagnetic (X- or O-) modes, which significally reduces the efficiency of Cherenkov source. The CR pattern is also directed almost perpendicular to the source magnetic line $\left(R P \simeq 80^{\circ}\right)$; and under different conditions of wave transformation, a large variation of S-burst shapes can occur (see Zaitsev, et al., 1986; Boev, et al., 1993).

Jupiter and Io are binding by a flux tube along a magnetic field line. Io's electromotive force accelerates and ionizates the electrons along the Io - Jupiter flux tube (IFT) and they elongated to magnetic field line in a weakly ionized plasma. The MHD Alfven (A) waves activate the processes of electron acceleration and the formation of bunched ejection that are the sources of S-bursts emissions.

The mechanism of acceleration of electrons may turn to runaway effects in electric fields in the region of the Io-Jupiter flux tube (see Boev et al., 2001). It was shown that the electric fields which induced by the Io tube movement increase the value of runaway Dreiser threshold. The maximum electric fields corresponding to $\mathrm{A}$ and $\mathrm{B}$ sources in the northern hemisphere are reached at longitudes $\lambda_{I I I s}=(100-150)^{\circ}$ and $(170-250)^{\circ}$. Moreover, these electric field values almost exceed the Dreiser threshold in the northern hemisphere, and the electron beams can be generated at all longitudes, which responded to the S-bursts generation on this hemisphere. So, the southern hemisphere of Jupiter it is able to accelerate electron beams only in narrow selected areas; and the southern hemisphere is more variability to L-bursts generation.

\section{Sizes of the sources from spectral data}

The source sizes were simple estimated by spectra data of L- and S-bursts as size by burst duration (the transverse source size by longitudes) and size by height (by frequency data). The evolution of bursts in the DAM Io-B-storm of 30.10.2008 (the observations of Ryabov, et al., 2014) is analyzed in detail. It is consisting with a large number of S-bursts, as well as them alternating with L-bursts and N-bursts. The results of the analysis are given in the Tables 1, 2 .

The Table 1 show the data of burst set: UT is the universal time of observed spectrum (the fragments of $2 \mathrm{MHz}$ frequency width and by $1 \mathrm{~s}$ duration); $\lambda_{I I I}$ is Jupiter's central meridian longitude (CML) at this UTtime moment; $\lambda_{I I I s}$ is the longitude of source location (when Io phase is $\Phi_{I o}=93-98^{\circ}$ ); $F$ is the frequency (in $\mathrm{MHz}$ ) where bursts observed. $\Delta T_{i}$ is instantaneous
Table 1: Spectral data of storm at 30.10.2008 and transverse sources size $\left(\Delta L_{i}\right)$ by time data

\begin{tabular}{|c|c|c|c|c|c|}
\hline $\begin{array}{l}\text { UT, } \\
\text { hr:min }\end{array}$ & & $\lambda_{I I I}$ & $\lambda_{I I I s}$ & & \\
\hline $15: 46$ & & 197 & 131 & & \\
\hline $15: 52$ & & 200 & 133 & & \\
\hline $15: 52(\mathrm{~N})$ & & & $66 ?$ & & \\
\hline $16: 00$ & & 205 & 140 & & \\
\hline $16: 26$ & & 216 & 154 & & \\
\hline $16: 26(\mathrm{~L})$ & & & 154 & & \\
\hline$\overline{\mathrm{UT},}$ & $\overline{\mathrm{F}}$, & $\overline{\text { Burst }}$ & 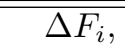 & $\overline{\Delta \Delta T_{i}}$ & 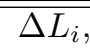 \\
\hline hr:min & $\mathrm{MHz}$ & type & $\mathrm{MHz}$ & ms & $\mathrm{km}$ \\
\hline $15: 46$ & 23 & S, Io B & $0.1 . .0 .5$ & $0.2 . .2$ & 0.008 \\
\hline \multirow[t]{2}{*}{$15: 52$} & 22 & $\mathrm{~S}$, rain & 0.2 & 2 & - \\
\hline & 16.8 & $\mathrm{~S}$, Io B & 0.3 & 1 & 0.007 \\
\hline $15: 52$ & 16.4 & $\begin{array}{r}\mathrm{N}, \\
\text { not } \mathrm{I} \text { ? }\end{array}$ & 0.1 & 0.5 & 0.005 \\
\hline \multirow[t]{3}{*}{$16: 00$} & 27.5 & S, Io B & 0.3 & 5 & 0.03 \\
\hline & 22.5 & $\mathrm{~S}$ & 0.4 & 6 & 0.035 \\
\hline & 19 & $\mathrm{~S}$ & 0.6 & 7 & 0.04 \\
\hline \multirow[t]{3}{*}{$16: 26$} & 31 & S, Io B & 0.2 & 10 & 0.06 \\
\hline & 27 & $\mathrm{~S}$ & 0.2 & 12 & 0.08 \\
\hline & 24 & $\mathrm{~S}$ & 0.3 & 17 & 0.1 \\
\hline $16: 26$ & 18 & $\mathrm{~L}$ & 0.6 & $>1000$ & $>6$ \\
\hline
\end{tabular}

burst duration, and $\Delta L_{i}$ is transverse source size, corresponded to $\Delta T_{i}$.

The Table 2 continues the Table 1, and it show the characteristics of the JRE sources obtained by frequency spectral data. $B_{M C R}$ corresponds to the magnetic field of burst source by MCR model (when observed frequency $F=1.1 \omega_{b e}\left(B_{M C R}\right) /(2 \pi)$, considering the disperse wave condition). $B_{C R}$ corresponds to the magnetic field in Cherenkov source model (when $\left.(2 \pi F)^{2}=\omega_{b e}\left(B_{C R}\right)^{2}+\omega_{p e}^{2}\right)$. The burst drift (see Drift in Table 2, in $\mathrm{MHz} / \mathrm{s}$ ) corresponds the source velocity of $u_{s}$, which is slightly relativistic (near $0.1 c$, $\left.c=3 \cdot 10^{10} \mathrm{~cm} / \mathrm{s}\right)$. The terms of $h_{s N}$ and $h_{s S}$ are the height of source location (by MCR model) for northern and southern hemisphere, respectively; $\Delta h_{i}$ is length of the source (in $\mathrm{km}$, along magnetic line or to height direction). If we assume that $\mathrm{S}$-bursts occur the most likely in the northern hemisphere of Jupiter, there is S-source locate in this storm of the height $(0-0.2) R_{j}$ (by the frame of MCR model) and at longitudes $\lambda_{I I I s}$ $=(195-220)^{\circ}$, when Jupiter is turned to the observer at longitude $\mathrm{CML}=\lambda_{I I I}=(130-160)^{\circ}$.

The train of S-bursts are induced and modulated by the Alfven (A) wave. This fact show the wide-lanes modulation on spectrum data by $0.5-1 \mathrm{MHz}$ width and slow drifting, corresponding to A-wave lengths (see $\lambda_{A S}$ and $\lambda_{A N}$ columns in table 2) and wave velocity $\left(c_{A}\right)$. According to the storm, S-bursts are inducted by A-waves that go both away from Jupiter and to the Jupiter, that propagating with velocity about $c_{A}$ 
Table 2: The characteristics of JRE-sources in the Io B storm at 30.10.2008 and heights-length $\left(h_{s}, \Delta h_{i}\right)$ of these sources by frequency spectral data, acording to northern $\left(h_{s N}\right)$ and sourthen $\left(h_{s S}\right)$ hemisphere (see the text more). Source or Alfven wave velocities $\left(u_{s}, c_{A}\right)$ are in units of light velocity $c$; heights of source are in units of $R_{j}$

\begin{tabular}{lrrrrrrrrrrr}
\hline $\begin{array}{l}\text { Time, } \\
\text { hr:min }\end{array}$ & $\begin{array}{r}\text { Freq., } \\
\text { MHz }\end{array}$ & $B_{M C R}$ & $B_{C R}$ & $\begin{array}{r}\text { Drift, } \\
\mathrm{MHz} / \mathrm{s}\end{array}$ & $u_{S} / c$ & $c_{A} / c$ & $h_{s N}$, & $h_{s S}$, & $\lambda_{A N}$ & $\lambda_{A S}$ & $\Delta h_{i}$, \\
$\mathrm{km}$ & $R_{j}$ & $R_{j}$ & $\mathrm{~km}$ & $\mathrm{~km}$ \\
\hline $15: 46$ & 23 & 7.2 & 5.6 & -22 & 0.08 & -0.001 & 0.13 & 0.24 & 2100 & 4300 & 140 \\
$15: 52$ & 22 & 7.1 & 5.4 & -21 & 0.08 & 0.0001 & 0.14 & 0.25 & 800 & 3570 & 140 \\
& 16.8 & 5.4 & 4.3 & -13.5 & 0.07 & 0.0006 & 0.21 & 0.34 & 2800 & 5700 & 280 \\
$15: 52(\mathrm{~N})$ & 16.4 & 4.7 & 3.64 & -5.1 & 0.03 & 0.0003 & 0.22 & 0.22 & 300 & & 150 \\
$16: 00$ & 27.5 & 8.7 & 6.8 & -30 & 0.09 & 0.0004 & -0.02 & 0.16 & 710 & 1400 & 110 \\
& 22.5 & 7.1 & 5.5 & & 0.1 & 0.0005 & 0.12 & 0.24 & 1100 & 2100 & 180 \\
& 19 & 6.1 & 4.8 & -27 & 0.11 & 0.0007 & 0.16 & 0.3 & 1800 & 3500 & 320 \\
$16: 26$ & 31 & 10 & 7.8 & -30 & 0.09 & -0.0001 & -0.02 & 0.15 & 710 & 1400 & 61 \\
& 27 & 8.7 & 6.8 & -30 & 0.09 & & -0.02 & 0.15 & 1100 & 2100 & 71 \\
& 24 & 7.7 & 6 & -30 & 0.1 & -0.0001 & 0.04 & 0.22 & 1800 & 3500 & 180 \\
$16: 26(\mathrm{~L})$ & 18 & 5.9 & 4.5 & $0.1 ?$ & - & 0.0002 & 0.1 & 0.35 & 1100 & 2100 & 50 \\
\hline
\end{tabular}

$=0.0005 c$, which is in $2-3$ times slower than the Awave velocity predicted by plasma parameters "theoretically" (0.001c). These Alfven waves have $\lambda_{A} \sim$ $1000 \mathrm{~km}$, and the A-waves may change the direction by reflection on Jupiter by $T_{A} \sim 10 \mathrm{~min}$ (the table 2 indicate the change of A-wave direction, but we do not obtained $T_{A}$ because of spectra fragmenting). The start of Io-B-storm is associated with sources at higher altitudes, and when time over, the sources drop down to Jupiter as $\mathrm{O}_{4}$ (Acuna, 1975) magnetic field model predicted, despite of observed S-bursts frequencies increase with time.

There are observed L- and N-bursts simultaneously with S-bursts in this storm. Thus, L-bursts can be associated with source from the other (southern) hemisphere of Jupiter, against of S-bursts associate with northern hemisphere. The other way, N-bursts may likely arise outside the Io-Jupiter tube, and can be located in the northern hemisphere at $\lambda_{I I I s}=65^{\circ}$ and at heights of $0.2 R_{j}$ (at this longitudes).

On using the spectral data, there were determined the sizes (thickness and length) of the filamentous sources of the JRE-electron-beams and the parameters of the burst-activate MHD (Alfven) waves. It is shown that the source of L-radiation the most likely looks like as thin filaments elongated along a magnetic field with a thickness of $\Delta L_{i} \simeq 50 \mathrm{~km}$ and a length of higher $1000 \mathrm{~km}$. The other way, S-radiation sources look like as bunches of filamentary outbursts (plasma clots) with a thickness of $\Delta L_{i}=(10-100) \mathrm{m}$ (of 10-100 threads per bunch), and a length of $\Delta h_{i}=(100-300) \mathrm{km}$, flying away from Jupiter with speed (0.05-0.1)c.

The fine structure of the DAM bursts in this storm detects the diffraction modulation of the JRE within the "lanes" by the frequency of $(0.2-1 \mathrm{MHz})$ and by time (up to $T_{r e p}=1 \mathrm{~min}$ ). On using the Arkhipov model $(2003,2007)$, it is possible to estimate the size of the sources by the diameter of the first Fresnel zone $\left(d_{1}=\sqrt{8 \pi c D / \omega_{b 0}}\right)$, and by the repetition periods $\left(T_{r e p}\right)$ of scattering inhomogeneities $\left(d_{2}=2\right.$ $\left.\pi D T_{r e p} / T_{j}\right)$, assuming that the scattering inhomogeneities are located of distance $(D)$ in close Jupiter's magnetosphere bounded by the Io torus $\left(T_{j}\right.$ is orbital period of Jupiter). These estimates confirm the size of the S-source is less than $200 \mathrm{~km}$.

\section{Discussion and theoretical interpretations}

There are made conclusions about the theoretical prerequisites for the appearance of DAM JRE bursts with observed parameters. We may estimate the power intensity $I_{\text {est }}$ of the source of Jupiter's DAM radiation by S-source volume $\left(V_{j s}=\Delta L_{i} \Delta h_{i}^{2}\right)$ :

$I_{e s t}=\gamma_{\omega} E_{i s} /\left(\omega_{b 0} S_{j s}\right)=\left(\gamma / \omega_{b 0}\right)\left(\gamma m_{e} c^{2} V_{j s}\right)\left(0.1 n_{e 0}\right)$

Here $\gamma_{\omega}=10^{-4} \omega_{b 0}$ is radiation increment, $\gamma=1.004$, $\omega_{b 0}=2 \pi \cdot 20 \mathrm{MHz}, n_{e 0}=10^{6} \mathrm{~cm}^{-3}$ is electron density, $E_{j s}$ is source energy, $S_{j s}=4 \pi(4 \mathrm{a} . \mathrm{u} .)^{2} \Delta R P$, we find for S-source: $I_{\text {est }}=2 \cdot 10^{5} \mathrm{Jy}$. This intensity is some lower then observed ones, $10^{6} \mathrm{Jy}$ (see Ryabov, Gerasimova, 1990), and this fact pointed us about the additional amplification of the source radiation near the generation region. This suggests an inhomogeneous structure of the medium in active S-bursts zone. The power of L-radiation is easily to match with they sizes.

The sources of Jupiter's radio emission in all ranges of radio waves are easily explained with runaway mechanism. The fine transverse structure of the S-sources may be explained by the mechanism of electron fluctuations, with periods are considered with time scattering of electron and atoms, $\tau=\tau_{e a}=10 \mathrm{~ms}$, and source transverse size is compared to the length of emitted waves $(10 \mathrm{~m})$. It is connected with the features of the bunching of electron-plasma blobs that lead to electron 
runaway and to the emission of plasma bunches. Alternatively, for the L- sources we are: $\tau=\tau_{i}=1 \mathrm{~s}$ (time scattering of ion and atoms), and this is compared to the time of forming of plasma blobs and thick current treads. The observed reducing the A-wave velocities in comparison with the "theoretical" ones can be explained by the influence of the Io - Jupiter flow tube and the reflection events on the propagation of MHD waves.

We use mainly in spectrum interpretation the MCR model. There are need to study additionally the fine structure of all DAM sources with the UTR-2 and GURT observation, as well as to study theoretically, with attracting a possible Cherenkov mechanism for the S- and N-bursts interpretations.

\section{References}

Acuna M.H.: 1975, Nature, 253, 327.

Arkhipov O.V.: 2003, Kinemat. Phys. Celest. Bod., Zaitsev V.V., et al.: 1986, Astron.Astroph., 169, 345.

Arkhipov O.V., Ruker H.O.: 2007, Astron. Astroph., 467, 353.

Boev A.G., Lukyanov M.Yu.: 1991, Sov. Astron., 35, 422.

Boev A.G., Lukyanov M.Yu., Tsvyk N.: 1993, Kinemat. Phys. Celest.Bod., 9, 27.

Boev A.G., Lukyanov M.Yu., Tsvyk N.: 1993, Kinemat. Phys. Celest.Bod., 9, 37.

Boev A.G., Udaltsova N.M., Yantsevich A.A.: 2001, Radioph. Radioastron., 6, 252.

Leblanc Y., Bagenal F., Dulk G.A.: 1993, Astron. Astroph., 276, 603.

Melrose, D.B.: 1986, J. Geohys. Res., 91, A7, 7970.

Ryabov B.P., Gerasimova N.N.: 1990, Decameter sporadic radioemission of Jupiter (in Russian), Kyiv: Naukova dumka, 240 p.

Ryabov V.B., et al.: 2014, Astron. Astroph., 268, A53.

Wu C.S.: 1985, Space Sci. Rev., 41, 215.

19, 267. 